\title{
Improving Indonesian Language Learning Results Through The Demonstration Method On The Materials to Find Vocabulary Related to Unhealthy Environment Class II SDN 01 Pasir.
}

\section{Mitsni Soifah}

SD Negeri 01 Pasir

mitsnisoifahtoyib@gmail.com

\section{Article History}

accepted 14/11/2020

approved $21 / 11 / 2020$

published 26/11/2020

\begin{abstract}
This study entitled "Improving Indonesian Language Learning Outcomes through demonstration methods of vocabulary materials related to the unsanitary environment of Class II SDN 01 Pasir". The purpose of this research is to improve student learning outcomes in Indonesian lessons. The research conducted was classroom action research (PTK). The stages are planning, implementing, observing, and reflecting. As for the indicator of increasing the ability of class II SDN 01 Pasir students, it was shown the acquisition of scores in the pre-cycle with a percentage of $21.05 \%$ that had been completed. Then there was an improvement in learning cycle 1, it was shown that there was an increase with the percentage of $52.63 \%$ that had been completed, so the researcher carried out the second cycle by obtaining a significant increase with the percentage value of $97.3 \%$ that had been completed. The results show that the demonstration method can improve student learning outcomes, especially in class II Indonesian language lessons at SDN 01 Pasir.
\end{abstract}

Keywords: Learning results, demonstration method

\section{Abstrak}

Penelitian ini berjudul "Peningkatan Hasil Belajar Bahasa Indonesia Melalui Metode demonstrasi Materi kosa kata yang berkaitan dengan lingkungan tidak sehat Kelas II SDN 01 Pasir". Tujuan dari penelitian ini adalah meningkatkan hasil belajar peserta didik pada pelajaran Bahasa Indonesia. Penelitian yang dilakukan adalah penelitian tindakan kelas (PTK). Adapun tahapannya adalah perencanaan, pelaksaan, observasi, dan refleksi. Adapun indikator peningkatan kemampuan siswa kelas II SDN 01 Pasir tersebut ditunjukkan perolehan nilai pada pra siklus dengan prosentase $21,05 \%$ yang telah tuntas. Maka diadakan perbaikan pembelajaran siklus 1 ditunjukkan ada peningkatan dengan prosentase $52,63 \%$ telah tuntas maka peneliti melaksanakan siklus yang ke dua dengan memperoleh peningkatan yang signifikan denga prosentase nilai $97,3 \%$ yang telah tuntas. Hasil menunjukkan bahwa metode demonstrasi dapat meningkatkan hasil belajar peserta didik khususnya pada pelajaran Bahasa Indonesia kelas II di SDN 01 Pasir.

Kata kunci: Hasil belajar Bahasa Indonesia, metode demonstrasi.

Social, Humanities, and Education Studies (SHEs): Conference Series https://jurnal.uns.ac.id/shes

p-ISSN 2620-9284 e-ISSN 2620-9292 


\section{PENDAHULUAN}

Kenyataan mata pelajaran menjadi momok dan membosankan bagi pesreta didik yang menganggap bahwa Bahasa indonesia adalah mata pelajaran yang perlu hafalan, hal ini dikarenakan luasnya materi.

Disamping factor siswa, tak kalah pentingnya factor guru dalam menyajikan pembelajaran memakai metode yang kurang menarik minat siswa yang mengakibatkan merasa jenuh dan membosankan sehingga tidak terjadi interaktif kedua belah pihak.

Kondisi psikologis siswa SD yang berada pada tahap berpikir konret (Ruseffendi 1980) merupakan kunci perlakuan guru dalam pembelajaran Bahasa Indonesia. Dilain pihak, Bahasa indonesia merupakan ilmu yang berdsifat dedukatif aksiomatik dan objek yang dipelajari bersifat abstrak (Fakta, konsep, dan prinsip).Krakteristik Baha Indonesia yang ilmunya bersifat dedukatif dan objeknya abstrak menyebabkan Bahas Indonesia menjadi mata pelajaran yang sulit bagi siswa SD yang masih berpikir konkret. Akibatnya sangat dimungkinkan bahwa banyak siswa yang mengalami kegagalan dalm pelajaran Bahasa Indonesia.

Kegagalan belajar Bahas Indonesia ini juga dialami oleh siswa kelas II SDN 01

Pasir. Pengalaman penulis menyebutkan bahwa rata-rata kelas yang mampu dicapai siswa sangat rendah. Kegagalan atau kesulitan belajar Indonesia yang dialami siswa terutama pada materi mencari kosa kata yang berkaitan dengan lingkungan tidak sehat.

Penyebab kegagalan Bahasa Indonesia ini selain disebabkan karena materinya sulit, juga karena guru belum menemukan metode/model pembelajaran yang dapat memberi pemahaman konseo yang lenih baik dan dapat mengaktifkan secara fisik maupun mental siswa dalam belajar. Selama ini guru banyak menggunakan metode ceramah dalam pembelajaran Bahas indonesia, kurang memperhatikan keterlibatan siswa, siswa terbiasa pasif, interaksi dalam kelas didomonasi guru. Siswa tidak terlatih untuk mengajukan pertanyaan, mengemukakan pendapat, berinteraksi aktif dengan sesame teman.Selain itu terjadi kesenjangan nilai antara siswa yang pandai (kelompok atas) dengan siswa yang kurang atau bahkan tidak pandai (kelompok bawah).

Karakteristik objek Basa Indonesia yang abstrak dan tahapannya berpikir siswa SD yang masih tahapannya berada tahap berpikir konkret ini membutuhkan perhatian yang sungguh-sungguh dan siswa, guru dan institusi yang menghasilkan guru SD atau yang terkait lainnya.Dalam hal ini untuk memperoleh pemahaman Bahas Indonesia yang baik dibutuhkan aktifitas yang tinggi.Oleh karena itu perlu diciptakan kondisi belajar yang menyenangkan, dalam arti bahwa proses pembelajaran Bahasa indonesia dapat menjadi suatu kegiatan yang diminati oleh siswa. Slameto (1995:57) menyatakan bahwa kegiatan yang diminati seseorang akan memperhatikan secara terus-menerus dan disertai rasa senang.

Menurut Bigge dalam Satmoko (1989:72) setiap guru memiliki teori belajarnya masing-masing. Teori tersebut merupakan pandangan yang integral dan sistematis.

\section{METODE}

Penelitian ini adalah Penelitian Tindakan Kelas (classroom action research) dengan menerapkan metode demonstrasi. Menurut Kurt Lewin dalam Kunandar (2011:42) penelitian tindakan kelas ini terdiri dari empat tahapan dasar yaitu perencanaan (planning), pelaksanaan (acting), pengamatan (observing), dan refleksi (reflecting).Analisis penelitian ini adalah analisis deskripsi kuantitatif,kualitatif dimana dalam penelitian ini selain penyajian hasil berupa data maupun angka peneliti juga menentukan bagaimana cara pengolahan hasil penelitian yakni dengan membuat analisisnya dengan menerapkan metode demonstrasi. Penelitian ini dilaksanakan pada peserta didik kelas II SDN 01 Pasir. Siklus I dilaksanakan pada tanggal 16 November 2020 dan siklus II dilaksanakan pada tanggal 23 November 2020.Teknik pengumpulan data yang dilakukan dengan observasi dan tes, baik pre tes maupun post 
tes.Observasi keterlaksaan metode demonstrasi, sikap peserta didik dan keterampilan.Untuk hasil belajar menggunakan tes pada LKPD.

\section{HASIL DAN PEMBAHASAN}

Pada pelaksanaan siklus I diadakan pre tes dan post tes,untuk mengetahui prkembangan peserta didik selama pembelajaran.Siklus I membahas materi tentang kosakata lingkungan tidak sehat.Pembelajaran dengan metode demonstrasi dilaksanakan secara berurutan mulai dari menentukan pertanyaan mendasar, merancang proyek,menyusun jadwal,memantau proses proyek, penilaian hasil dan evaluasi pengalaman.proyek yang dibuat peserta didik adalah menulis kosakata yang mereka sebutkan dengan Bahasa sendiri.Berikut ini adalah hasil belajar peserta didik yang bisa dilihat pada tabel berikut.

Tabel 1.Hasil Belajar Peserta Didik Siklus I

\begin{tabular}{llcll}
\hline No & Kondisi & $\begin{array}{c}\text { Jumlah Siswa } \\
\text { Tuntas }\end{array}$ & Nilai Rata- rata & $\begin{array}{l}\text { Persentase } \\
\text { Ketuntasan }\end{array}$ \\
\hline 1 & $\begin{array}{l}\text { Kondisi } \\
\text { awal }\end{array}$ & 17 & 67 & $58 \%$ \\
\hline 2 & Siklus I & 22 & 76 & $72 \%$ \\
\hline 3 & Siklus II & 24 & 80 & $83 \%$ \\
\hline 4 & Siklus III & 26 & 84 & $90 \%$
\end{tabular}

Berdasarkan data di atas, nilai rata -rata hasil belajar siswa mengalami peningkatan pada siklus I 76 meningkat menjadi 80 pada siklus II dan meningkat menjadi 84 pada siklus III. Ketuntasan belajar klasikal pada siklus I $72 \%$ meningkat menjadi $83 \%$ pada siklus II dan meningkat menjadi $90 \%$ pada siklus III.

Berdasarkan hasil pembahasan dapat disimpulkan bahwa penggunaan metode demonstrasi dapat meningkatkan hasil belajar siswa pada pelajaran Bahasa Indonesia materi mencarai kosakata yang berkaitan dengan lingkungan tidak sehat hal ini sesuai dengan konsep atau teori yang diungkapkan oleh Muhibbin 2020 menyatakan bahwa Metode demonstrasi adalah metode mengajar dengan cara memperagakan barang, kejadian, aturan, dan urutan melakukan sesuatu kegiatan, baik secara langsung maupun melalui penggunaan media pengajaran yang relevan dengan pokok bahasan atau materi yang sedang disajikan. Sehingga pernyataan tersebut membuktikan bahwa metode demontrasi dapat meningkatkan hasil belajar peserta didik.

\section{SIMPULAN}

Penerpan metode demonstrasi dapat meningkatkan hail belajar peserta didik kelas II pada pelajaran bahasa Indonesia materi mencari kosa kata yang berkaitan dengan lingkungan tidak sehat.peningkatan yang tejadi karena adanya kesan pembelajaran yang mendalam dari peserta didik terhadap materi yang diajarkan melalui setiap proyek yang dibuat.peserta didik akab selalu teringat akan materi yang 
diajarkan dikarenakan mereka meenemukan dan membangun sendiri pengetahuan mereka pada saat membuat proyek yang sudah disepakati.

\section{DAFTAR PUSTAKA}

Kurt Lewin M. Keller. (1970), Instructional Design Theory and Models : An Overview of Their Current Status, Charles M. Regeluth (ed), Lawrence Erlbaum Associates, London.

Syah, M. (2010). Psikologi Belajar. Bandung.

Syaiful Bahri, D. (2000). Guru dan Anak Didik dalam Interaksi Edukatif.

Rusefendi, E. T. (1991). Pengantar Kepada Guru Pengembangan dalam Pengajaran Matematika untuk Meningkatkan CBSA. Bandung: Transito.

Slameto. (2010). Belajar dan faktor-faktor yang mempengaruhinya. Jakarta: PT. Rineka Cipta. 